\title{
Penerapan Komunikasi Penyuluhan Pertanian Milenial pada Pusat Pelatihan Pertanian dan Pedesaan Swadaya (P4S) di Desa Betet Kabupaten Nganjuk Jawa Timur
}

\author{
The Application of Millennial Agricultural Extension Communication at the \\ Self-help Agricultural and Rural Training Center (P4S) in Betet Village, \\ Nganjuk Regency, East Java
}

\author{
Sekar Renaningtyas ${ }^{1} \&$ Puji Hariyanti ${ }^{2}$ \\ 1,2 Program Studi Ilmu Komunikasi, Universitas Islam Indonesia, Sleman \\ Yogyakarta, Indonesia
}

\section{Author's email: \\ Email: \\ 117321156@students.uii.ac.id \\ 2 puji.hariyanti@uii.ac.id}

\begin{abstract}
$P 4 S$ is an agricultural extension agency established, owned, and managed by independent farmers. This study aims to analyze the communication model carried out by P4S as an extension agent in conducting counseling for the Millennial Farmer program carried out in Betet Village, Ngroggot District, Nganjuk Regency. The method used is a field qualitative method. The results showed that there were two phases in the extension of millennial farmers. In the pre-extension until the extension, the communication model used was linear so that in the pre-extension the models applied were unidirectional SMCR and two-way SMCR. After the extension, the communication model used is the network communication model and the forum media communication model.
\end{abstract}

Keywords: Communication models, Millennial Farmers, Empowerment Communication

P4S merupakan lembaga penyuluhan pertanian yang didirikan, dimiliki dan dikelola oleh petani yang telah swadaya. Penelitian ini bertujuan untuk menganalisis model komunikasi yang dilakukan P4S sebagai lembaga penyuluh dalam melakukan penyuluhan program Petani Milenial yang dilakukan di Desa Betet Kecamatan Ngroggot Kabupaten Nganjuk. Metode yang digunakan adalah metode kualitatif lapangan. Hasil penelitian menunjukkan bahwa ada dua fase dalam penyuluhan petani milenial. Pada pra penyuluhan hingga saat penyuluhan, model komunikasi yang digunakan linear sehingga pada pra penyuluhan model yang diterapkan adalah SMCR searah dan SMCR dua arah. Pada pasca penyuluhan, model komunikasi yang digunakan adalah model komunikasi jejaring dan model komunikasi media forum.

Kata kunci: Model komunikasi, Petani Millennial, Komunikasi Pembangunan. 


\section{PENDAHULUAN}

Petani Milenial merupakan program yang diciptakan oleh Kementerian Pertanian. Program ini merupakan kegiatan untuk mengembangkan pertanian serta meregenerasi pertanian. Dalam program ini, Kementerian Pertanian ingin menumbuhkan semangat anak muda untuk melanjutkan estafet wirausaha pertanian di Indonesia, dan juga mengembangkan penggunaan teknologi internet guna menunjang produksi hasil tani untuk memenuhi permintaan pasar yang terus bertambah.

Badan Penyuluhan dan Pengembangan Sumber Daya Manusia Pertanian (BPPSDMP) melaksanakan program petani milenial melalui lembaga penyuluhan, yaitu Pusat Pelatihan Pertanian Pedesaan dan Swadaya (P4S). Ini merupakan lembaga yang memberikan pelatihan pertanian di pedesaan dengan menggunakan asas demokrasi, swadaya, pengembangan usaha, dan keterpaduan.

Keberadaaan $\mathrm{P} 4 \mathrm{~S}$ yang tersebar di setiap daerah membuat program petani milenial dapat dilaksanakan dengan merata. Hal ini dapat membuat pelatihan, penyuluhan dan pemberdayaan yang dilaksanakan akan menjadi efektif karena setiap daerah memiliki karakternya masing-masing untuk dilakukan program Petani Milenial. Penyuluhan merupakan jalan yang tepat dalam mengembangkan dan meningkatkan sumber daya manusia sehingga para petani dapat terus berkembang.

Salah satu daerah yang masih menjadikan pertanian sebagai mata pencaharian utama adalah Kabupaten Nganjuk meskipun peminatnya terus menurun. Alasan penurunan minat ini karena pertanian memiliki hasil yang tidak banyak. Adanya penebas yang langsung membeli hasil pertanian dengan harga yang sangat rendah menurunkan minat petani. Pemberdayaan yang dilakukan oleh pemerintah daerah setempat kebanyakan dalam bentuk memberikan modal berupa materi dan bantuan alat.

Perkembangan pola komunikasi dalam penyuluhan pertanian di Indonesia yang ditulis oleh Sadono (2009) menjelaskan walaupun penurunan minat dan hasil perekonomian petani menurun, sektor petani masih menjadi lapangan pekerjaan bagi sebagian besar penduduk di Indonesia. Selain itu, menjadi lumbung produksi dalam penghasilan devisa negara untuk ekspor non-migas. Pertanian juga menjadi benteng pertahanan perekonomian nasional saat terjadi krisis ekonomi.

Memasuki revolusi industri 4.0 yang memadukan teknologi dan internet, menjadi tantangan untuk dunia pertanian. Petani harus ikut terus bersaing untuk menghasilkan produk tani dan dapat memenuhi permintaan pasar. Tantangan itu harus dijalankan dengan memberdayakan petani menjadi petani yang mampu bersaing di era ini sehingga petani harus mampu dan bisa mengolah dan memproduksi hasil pertaniannya dengan memadukan teknologi dan internet.

Melalui Peraturan Mentri Nomor 4 tahun 2019 tentang Pedoman Gerakan Pembangunan Sumber Daya Manusia Pertaninan Menuju Lumbung Pangan 2045, dijelaskan bahwa pertani milenial merupakan petani yang berusia 19-30 tahun dan/atau petani yang adaptif terhadap teknologi dan inovasi (Menteri Pertanian Republik Indonesia, 2019). Petani Milenial tidak hanya berpatok pada usia saja. Petani milenial yang diutamakan adalah bagaimana pola pikirnya. Jadi, petani milenial bukan melulu ditujukan ada sumber daya manusia yang berusia 1930 tahun. 
Kepentingan program Petani Milenial adalah untuk menciptakan smart dan digital farming (Utami, 2020). Hal ini dianggap penting karena sumber daya manusia tidak ada yang abadi dalam arti akan ada masa habisnya. Dalam program Petani Milenial, ini para generasi milenial menciptakan sebuah sistem pertanian dengan basis smart dan digital faming yang nantinya dapat menjadi regenerasi dan juga menularkan sistem pertanian yang lebih efektif, ramah lingkungan dan juga memili hasil yang baik secara kualitas \& kuantitas.

Pertanian Milenial merupakan upaya pembangunan yang dilakukan oleh pemerintah kepada petani. Untuk itu, dalam menganalisis pola komunikasi yang tejadi, penelitian ini menggunakan teori komunikasi pembangunan. Komunikasi merupakan hal yang sangat penting dalam pembangunan sehingga perlu memahami elemen-elemen komunikasi SMRCE (Source, Message, Receiver, Channel, dan Effect) yang harus diterapkan dalam pembangunan.

Pola komunikasi mengenai penyuluhan pertanian telah terlebih dahulu dilakukan penelitian, seperti penelitian yang dilakukan oleh Hariani (2017) dari Universitas Halu Oleo. Penelitian ini melihat bagaimana pola komunikasi yang dilakukan oleh PPL dalam melakukan penyuluhan kepada petani cengkeh di Desa Wa ode Buri, Buton Utara. Pola komunikasi yang ditemukan adalah penerapan pola komuniasi satu arah, dua arah dan multiarah (Hariani, 2017). Nunung Nurhayati dalam penelitiannya mengenai Pola Komunikasi Balai Penyuluhan Pertanian Indramayu dalam Upaya Penyebaran Informasi Pertanian menyimpulkan bahwa penyampaian pesan dilakukan dengan formal dan tidak formal. Selain itu, bentuk penyampaian dari Balai Penyuluhan kepada petani atau sebaliknya adalah vertikal. Sebaliknya, penyampaian horizontal digunakan bagi sesama petani atau sesama penyuluh. Ketidakjelasan penyebaran informasi, sarana dan prasarana tidak memadai, perbedaan persepsi dan cara pandang menjadikan hambatan dalam penyebaran informasi. Selain itu, penelitan ini juga meninjau dari pemberdayaan petani seperti penelitian yang dilakukan oleh Laili (2014) dari Universitas Brawijaya. Penelitian ini menyimpulkan bahwa pemberdayaan yang dilakukan di Desa Betet sudah lebih baik untuk mewujudkan ketahanan pangan. Petani memiliki pengetahuan lebih sehingga hasil pertaniannya pun meningkat. Dukungan dari pemerintah dengan adanya subsidi bantuan dan benih. Hambatan yang terjadi adalah rendahnya kualitas sumber daya manusianya serta keterbatasan alat (Laili, 2014). Penelitian ini dilakukan untuk menganalisis model komunikasi yang dilakukan $\mathrm{P} 4 \mathrm{~S}$ sebagai lembaga penyuluh dalam melakukan penyuluhan program Petani Milenial.

\section{KERANGKA TEORI}

Komunikasi pembangunan memiliki artian luas dan sempit. Dalam artian luas, komunikasi pembangunan meliputi fungsi dan peran komunikasi dalam aktivitas pertukaran pesan dengan timbal balik antara masyarakat dan pemerintah yang dimulai dengan perencanaan, pelaksanaan dan evaluasi sebuah pembangunan. Dalam artian sempit, komunikasi pembangunan adalah cara penyampaian ide dan keterampilan suatu pembangunan yang muncul dari pihak prakarsa dengan sasaran pembangunnya, yaitu masyarakat agar memahami, menerima, dan berpartisipasi dalam pembangunan (Dilla, 2007)

Goulet dalam Theresia (2014) menjelaskan tentang nilai-nilai pembangunan. Pertama, swasembada, yaitu memiliki kemampuan dalam 
memenuhi atau mencukupi kebutuhan dasar. Ke dua, harga diri, yang merupakan kebebasan diri dari penindasan dan tidak dimanfaatkan oleh pihak lain. Ke tiga, kebebasan dimana seseorang mampu dalam memilih solusi untuk perbaikan mutu hidup sehingga mewujudkan kesejahterahaan.

Pembangunan akan menimbulkan perubahan sosial sehingga komunikasi memiliki peran penting. Ini karena komunikasi memiliki peran dalam mengubah cara berfikir, sikap, dan Tindakan seseorang dalam menyelesaikan masalah sosial. Namun, jika komunikasi terhambat akan membuat proses pembangunan menimbulkan ketimpangan. Fakta negara maju seperti perbedaan antara desa dan kota, jurang antara miskin dengan kaya. Hal ini akan berdampak pada bagaimana cara berfikir, bersikap, berperilaku, dan pendapat seseorang. Untuk itu, komunikasi merupakan hal yang sangat penting dalam pembangunan sehingga perlu memahami elemen komunikasi SMRCE (Source, Message, Receiver, Channel, dan Effect) yang harus diterapkan dalam pembangunan.

Komunikasi pertanian merupakan aktivitas bertukar pesan antar-manusia yang memiliki kaitan tentang kegiatan pertanian, secara pribadi maupun antarkelompok. Biasanya, memiliki sifat yang umum dengan menggunakan lambanglambang dalam penyampaiannya, dan umumnya dapat ditemukan dalam aktivitas penyuluhan pertanian (Soekartawi, 1988). Keduanya memiliki hubungan yang tidak dapat dilepaskan. Komunikasi pertanian merupakan ilmu pengetahuan yang tidak hanya dibutuhkan oleh petani saja sehingga masyarakat non petani juga membutuhkan ilmu ini. Namun, dalam penyuluhan pertanian para penyuluh perlu untuk mencari dan mempelajari komunikasi pertanian untuk disampaikan kepada para petani (Soekartawi, 1988).

Sukartiwi juga menjelaskan bahwa komunikasi pertanian yang dilakukan dalam penyuluhan dapat dikatakan berhasil jika seorang komunikator atau penyuluh dan komunikan atau audiens (petani) memiliki kesamaan persepsi dalam memahami ilmu pertanian yang diberikan oleh penyuluh. Oleh karenanya, wajib bagi seorang penyuluh memahami dengan mandalam mengenai komunikasi pertanian.

Model komunikasi merupakan cara untuk menggambarkan kembali mengenai fenomena komunkasi yang terjadi pada saat penyuluhan. Dalam pembentukan model, terdapat reduksi unsur-unsur komunikasi sehingga terdapat pengurangan unsur yang tidak berguna dan penenakanan pada unsur yang menonjol.

Model komunikasi Berlo adalah model komunikasi yang berasal dari sumber atau yang disebut sebagai komunikator untuk menyampaikan informasi kepada penerima atau komunikan melalui saluran-saluran komunikasai dengan harapan terciptanya dampak yang selaras dengan sumber (Sadono, 2009).

Model komunikasi hierarkis dua arah merupakan pengembangan dari model komunikasi kovergen. Dalam model ini, terjadi sebuah proses dimana setiap partisipan saling bertukar pesan untuk mencapai tujan dari komunikasi yang dilakukan (Sadono, 2009). Model ini menunjukan bahwa proses komunikasi yang terjadi mementingkan atau mengutamakan terjadinya pertukaran pesan, hal ini berdampak pada elemen komunikasi lainnya terutama pada efek dari pesan yang disampaikan. Dalam model komunikasi jejaring ini, komunikasi yang terjalin adalah hubungan timbal balik dari setiap partisipan. Model ini 
merupakan pengembangan dari SMCR searah dan SMCR dua arah karena melalui model ini penerima manfaat dari sebuah kegiatan komunikasi akan memberikan dampak kepada pihak yang memberikan pesan dan pencipta pesan (Sadono, 2009).

Model komunikasi media forum melibatkan media massa atau pada saat ini Mmedia sosial juga bisa menggantikannya. Media massa tersebut menjadi sumber yang digunakan oleh penyuluh untuk kemudian disebarkan kepada sasaran penyuluh dengan dilakukan pendampingan sehingga media dianggap kurang memiliki pengaruh yang besar kepada individu (Sadono, 2009).

\section{METODE}

Penelitian ini menggunakan metode penelitian kualitatif deskriptif. Alasan menggunakan metode tersebut karena penelitian ini bertujuan untuk mengetahui bagaimana interaksi sosial yang membentuk pola komunikasi dalam penyuluhan. Metode kualitatif digunakan untuk memahami interaksi sosial yang sangat kompleks dengan ikut terjun langsung ke lapangan dan melakukan wawancara mendalam sehingga dapat ditemukan bagaimana interaksi yang terjadi akan membentuk pola (Sugiyono, 2017).

Lokasi penelitian ini adalah Desa Betet Kabupaten Nganjuk Provinsi Jawa Timur, terletak di Kabupaten Nganjuk bagian Timur. Pengambilan data lapangan dilakukan pada Oktober hingga November 2020. Dalam melakukan pengumpulan data di lapangan, peneliti merekam hasil wawancara dan juga melakukan observasi lapangan tentang produk dari kegiatan yang dilaksanakan.

Dan data sekunder didapatkan oleh peneliti melalui hasil observasi lapangan dengan melihat produk terkait dengan program Petani Milenial dan juga dokumentasi dari kegiatan dari petani di Desa Betet.

Penelitian ini menggunakan analisis data model Miles \& Huberman (1992), yaitu melalui tahapan pengumpulan data, reduksi data, penyajian data dan menarik kesimpulan.

\section{HASIL DAN PEMBAHASAN}

\section{Upaya Pembangunan bidang Pertanian di Desa Betet}

Terdapat dua jenis pembangunan di Desa Betet, yaitu pembangunan secara fisik dan nonfisik. Pembangunan fisik dilakukan dengan memerbaiki sarana yang terkait dengan keperluan pertanian di Desa Betet seperti saluran air, pengadaan lahan praktik, pengadaan alat tanam dan alat panen. Pembangunan secara nonfisik berfokus pada pengembangan sumber daya manusianya dengan melakukan penyuluhan dan pelatihan yang terkait dengan pengembangan pertanian.

Goulet (Theresia, 2014) menjelaskan bahawa pembangunan haruslah memiliki nilai-nilai swasembada, harga diri, dan kebebasan. Nilai-nilai ini merupakan suatu bentuk tujuan dari pembangunan itu sendiri, yaitu kesejahteraan bagi sasaran pembangunan (masyarakat). Nilai Swasembada yang dimaksudkan adalah masyarakat dapat dan mampu untuk memenuhi kebutuhan dasar seperti halnya kebutuhan pokok, yaitu sandang, pangan, papan, termasuk kebutuhan-kebutuhan yang menyangkut pendidikan serta kesehatan jiwa dan raga. Pada nilai swasembada ini, pembanguan haruslah memiliki tujuan yang berdasarkan tentang apa yang sejatinya dibutuhkan secara mendasar oleh masyarakat sebagai sasaran pembangunan tersebut.

Di Desa Betet, nilai pembangunan swadaya diterapkan dengan memberikan 
pendidikan untuk petani berupa penyuluhan, dan nantinya dapat menjadikan petani memiliki proteksi diri atas ilmu yang dimilikinya. Selain itu, dalam pemenuhan kebutuhan pokok seperti pangan, petani dengan baik menyimpan hasil panen berupa beras yang sebagian besar disimpan dan memilih mejual hasil tani holtikultura. Dengan prinsip yang diterapkan oleh para petani di Desa Betet, yaitu tetap memertahankan kebutuhan pangan dan tidak terjadi kelaparan ataupun kehabisan bahan pangan pokok. Prinsip tersebut merupakan bentuk penerapan nilai swadaya.

Selanjutnya, nilai harga diri. Nilai yang dimaksudkan adalah tumbuhnya rasa percaya diri sehingga tidak dimanfaatkan oleh pihak lain demi kepentingan satu pihak yang artinya juga terhidar dari penindasan (Theresia, 2014). Nilai ini telah diterapkan ketika pemerintahan desa memberikan bekal kepada petani melalui penyuluhan sehingga petani memiliki kemampuan untuk mempertahankan apa yang mereka miliki dan tidak mudah untuk diombang-ambingkan oleh tengkulak pada saat menjual hasil panen. Terpenuhinya nilai swadaya berdampak pada tumbuhnya nilai harga diri pada petani.

Pelaksanaan pembangunan yang telah dilakukan juga mengandung nilai kebebasan. Nilai ini juga tumbuh karena kedua nilai sebelumnya juga terbangun. Pada nilai kebebasan ini, pembangunan ditujukan agar sasaran pembangunan memiliki kemampuan untuk memilih jalannya sendiri guna memperbaiki mutu hidup dan mewujudkan kesejahteraan. Pembangunan tanpa menanamkan nilai kebebasan menjadi percuma karena akan menjadi penghambat proses pembangunan itu sendiri. Sejatinya, pembangunan akan menimbulkan sebuah perubahan sosial yang tidak pernah berhenti untuk mengubah kehidupan masyarakat dengan capaian perbaikan mutu hidup. Ini dapat dilihat ketika petani mendapatkan penyuluhan terhadap masalah yang sedang dihadapi. Metode penyuluhan tersebut membuat petani mengerti dan bisa memutuskan apa yang akan mereka pilih untuk menyelesaikan permasalahan yang sedang dihadapi. Dengan demikian, terwujudlah perbaikan mutu hidup dan kesejahteraan itu sendiri. Selain itu, dengan dilakukan penyuluhan Petani Milenial ini, petani dapat memiliki kebebasan untuk mengatur lahan hingga memiliki kebebasan dalam memasuki dan menguasai pasar.

\section{Tujuan Penyuluhan Petani Milenial di Desa Betet}

Program Petani Milenial ini memiliki tujuan memberikan pola pikir yang baru. Dalam pola pikir yang baru ini, harapannya ada kejelasan untuk para petani. Petani diharapkan mampu memerhitungkan efisiensi, efektifitas, dan kualitas produk hasil tani dan juga menguasai pasar. Jika pola pikir yang baru ini dapat berjalan dengan baik melalui program petani milenial, maka para petani nantinya akan merasakan peningkatan kesejahteraan dengan keuntungan ataupun kerugian yang jelas sehingga para petani dapat menganalisis masalah yang akan dihadapi.

Hingga saat ini, permasalahan yang dihadapi oleh petani masih sama. Para petani merasakan ketidakpastian tentang yang harus dilakukan ketika masa panen datang. Ketika masa panen, para petani biasanya mengadalkan penebas. Untuk itu, tujuan program petani milenial ini adalah agar para petani dapat menguasai segala hal yang berhubungan dengan pertanian dengan bantuan teknologi dan juga internet

Karena pemberdayaan merupakan salah satu bentuk dari pembangunan, dapat dikatakan bahwa pembangunan sendiri 
memiliki tujuan untuk upaya perbaikan mutu manusia, baik ekonomi hingga sosial budanyanya. Tujuan pemberdayaan karenanya adalah agar masyarakat sendiri mengalami perbaikan kelembagaan (better institution), perbaikan usaha (better business), perbaikan pendapatan (better income), perbaikan lingkungan (better environment), perbaikan kehidupan (better living), perbaikan masyarakat (better community) (Theresia, 2014).

Perbaikan kelembagaan (better institution) merupakan upaya untuk memerbaiki sebuah kelembagaan yang harapan dalam kelembagaan itu dapat berpengaruh dengan pengembangan jejaring dengan pemangku kepentingan dan juga mitra yang terkait (Theresia, 2014). Dalam perbaikan lembaga, dilakuan reset atau pengaturan kembali. Pemberdayaan ini mengupayakan minat generasi muda untuk melanjutkan estafet dunia usaha tani. Ketika terjadi regerasi, kelembagaan pertanian di Desa Betet akan hadir dengan gaya yang baru dan terkini mengikuti berkembangnya zaman.

Perbaikan usaha (better business) merupakan dampak dari perbaikan yang pertama. Perbaikan usaha ini mengupayakan perbaikan pendidikan dalam bentuk meningkatkan semangat belajar sehingga menimbulkan harapan dalam memperbaiki bisnis/kegiatan yang dilakukan (Theresia, 2014). Perbaikan usaha dalam pemberdayaan melalui program Petani Milenial ini, petani diberikan ilmu yang terkait dengan pertanian. Fokus Petani Milenial ini adalah melakuan pertanian yang efektif, efisien dan ramah lingkungan.

Perbaikan pendapatan (better income) adalah dampak perbaikan usaha. Ini diharapkan akan membenahi usaha akan memiliki pendapatan yang lebih baik bahkan meningkat (Theresia, 2014). Program Petani Milenial dilaksanakan dengan menjalankan sistem budidaya tanaman dengan minim lahan sehingga para petani yang tidak memiliki lahan dapat melakuan budidaya tanpa harus mengeluarkan biaya sewa lahan, dan pendapatan pun meningkat.

Ketika pendapatan dan perbaikan usaha terjadi maka akan menciptakan perbaikan lingkungan. Hal ini dapat terjadi karena peningkatan pendapatan akan menekan angka kemiskinan, kerusakan lingkungan sering kali terjadi akibat kemiskinan dan pendapatan yang terbatas (Theresia, 2014). Ketika petani melaksanakan program Petani Milenial, dan merasakan pendapatan meningkat maka yang akan terjadi adalah perbaikan lingkungan baik secara alam dan juga lingkungan sosial

Tahapan selanjutnya adalah perbaikan kehidupan. Dalam tahapan ini, terdapat pengaruh antara pendapatan yang meningkat dan juga lingkungan yang baik. Jika ini terjadi maka akan tercipta kehidupan yang jauh lebih baik di setiap keluargnya (Theresia, 2014). Kesejahteraan mulai dirasakan oleh setiap keluarga yang mengikuti dengan baik atas pemberdayaan yang telah dilaksanakan dari awal.

Tujuan akhir pemberdayaan masyarakat adalah terwujudnya kehidupan masyarakat yang lebih baik. Ketika perbaikan perbaikan di atas saling berkesinambungan akan menciptakan masyarakat yang lebih baik pula (Theresia, 2014). Ketika setiap keluarga dapat merasakan kesejahteraan maka terciptalah kesejahteraan yang lebih besar dilingkungan tersebut. Ini akan menciptakan masyarakat yang lebih baik dan terciptalah masyarakat yang sejahterah dan terberdaya.

Tujuan permberdayaan juga merujuk dalam tujuan pembangunan pertanian, yaitu untuk mewujudkan perbaikan dalam teknis bertani (better farming), 
memperbaiki usaha tani itu sendiri, perbaikan mutu hidup petani. Selain itu, perbaikan akses dalam pemodalan petani serta pasar dan jaminan harga hasil produk tani (Theresia, 2014). Hal ini dimaksudkan untuk membuat petani memiliki kepastian dalam melakukan usahanya. Ketidakpastian yang dialami petani mulai dari cuaca hingga bagaimana produk hasil tani dihadapan pasar.

\section{Model Komunikasi}

Penelitian ini menggunakan model komunikasi yang biasa di gunakan dalam kegiatan pemberdayaan. Seperti yang telah di sebutkan dalam penelitian Sadono (2009), pola komunikasi dalam dunia pemberdayaan khusunya wirausaha tani terdapat beberapa model. Penelitian ini menggunakan 3 model dari gagasan Sadono dan dibagi menjadi 2 tahapan, yaitu Pra Penyuluhan dan Pasca penyuluhan

Dalam tahap pra penyuluhan ini, model komunikasi yang terjadi adalah model SMCR searah. Model Komunikasi SMCR searah ini adalah model komunikasi yang terjadi ketika fenomena komunikasi yang terjadi memiliki bentuk up to down. Selain itu, komunikasi yang dilakukan hanya searah tidak ada timbal balik dari setiap partisipan. Ini karena ide penyuluhan muncul dari kemeterian pertanian yang mewakili peneliti.

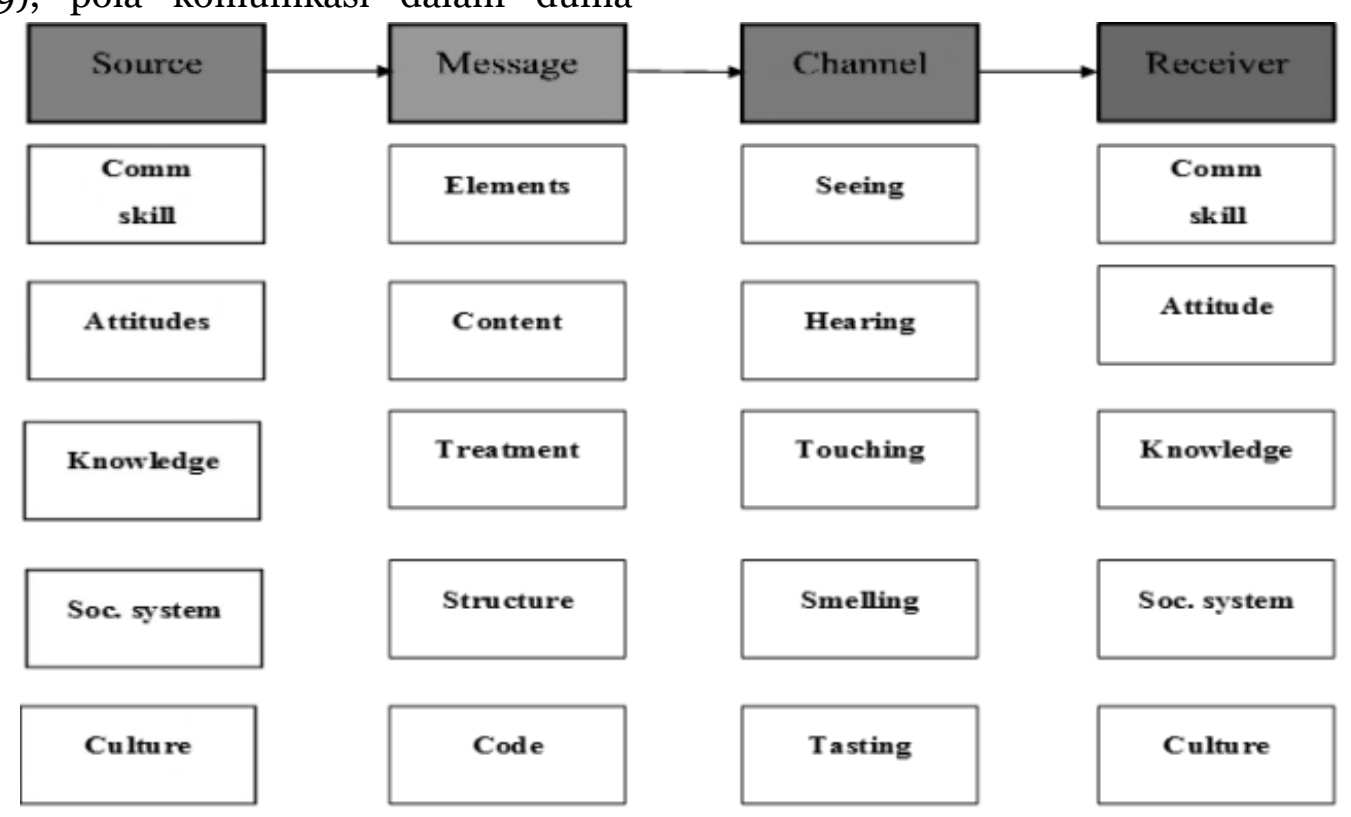

Gambar 1. Model Komunikasi SMCR searah

Informasi mengenai pertanian milenial muncul dari Kementerian Pertanian yang diturunkan kepada $\mathrm{P}_{4} \mathrm{~S}$ sebagai lembaga penyuluh yang paling dekat dengan petani. Kementerian pertanian memberikan kerangka yang harus disusun kembali oleh $\mathrm{P} 4 \mathrm{~S}$ agar menjadi lebih mudah dipahami oleh petani. $\mathrm{P} 4 \mathrm{~S}$ memberikan penyuluhan berdasarkan kisah sukses dari $\mathrm{P} 4 \mathrm{~S}$ yang 
dijadikan sebagai bentuk komunikasi penyampaian pesan. Ini adalah hal yang dilakukan $\mathrm{P} 4 \mathrm{~S}$ dalam menjadi kunci sebagai partisipan dalam menyampaikan pesan untuk keberhasilan penyampaian informasi yang ada. Dapat dikatakan bahwa $\mathrm{P}_{4} \mathrm{~S}$ merupakan saluran komunikasi yang digunakan oleh Kementrian Pertanian untuk menyampaikan program Petani Milenial di Desa Betet.
Pada saat dilakukan penyuluhan, P4S diawali dengan membuka sesi tanya jawab terlebih dahulu sebelum dimulainya penyuluhan. Melalui temuan, model komunikasi yang dilakukan adalah SMCR dua arah. Ini karena terjadi hubungan timbal balik antara penyuluh dan juga sasaran penyuluhan. Hubungan timbal balik ini membuat penyuluh memberikan topik penyuluhan yang berasal dari masalah yang sedang dan akan di hadapi oleh petani, tetapi tetap dalam satu tema atau topik yang akan disampaikan

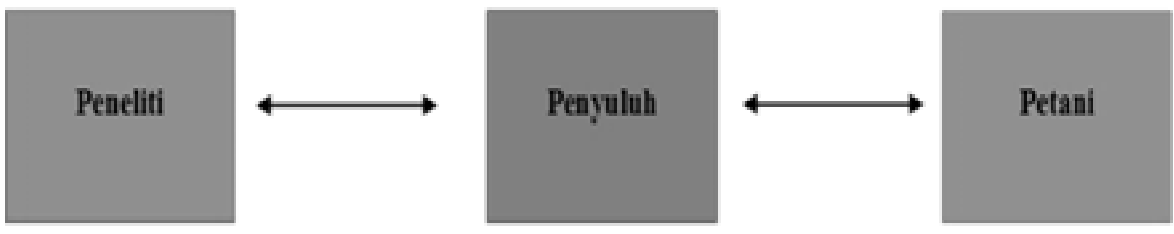

Gambar 2. Model komunikasi SMCR dua arah

Model komunikasi SMCR dua arah memadukan program yang sedang dijalankan dengan kunjungan yang terjadwal kepada sasaran penyuluhan. Ini sama seperti pendekatan yang dilakukan oleh $\mathrm{P}_{4} \mathrm{~S}$ dengan memberikan penyuluhan kepada petani di Desa Betet, dimana $\mathrm{P}_{4} \mathrm{~S}$ mendatangi sasaran penyuluhan dan melakukan komunikasi dua arah kepada sasaran penyuluhannya.
Model Komunikasi yang terjadi pada saat pasca penyuluhan jika dilihat dari temuan yang ada di lapangan terdapat beberapa model. Pertama adalah model komunikasi jejaring. Dalam model ini, terdapat hubungan yang timbal balik antara penyuluh dan juga petani. Model ini menggunakan media sosial sebagai saluran atau channel untuk menyampaikan dan menyelesaikan permasalahan yang diajukan oleh para petani. 


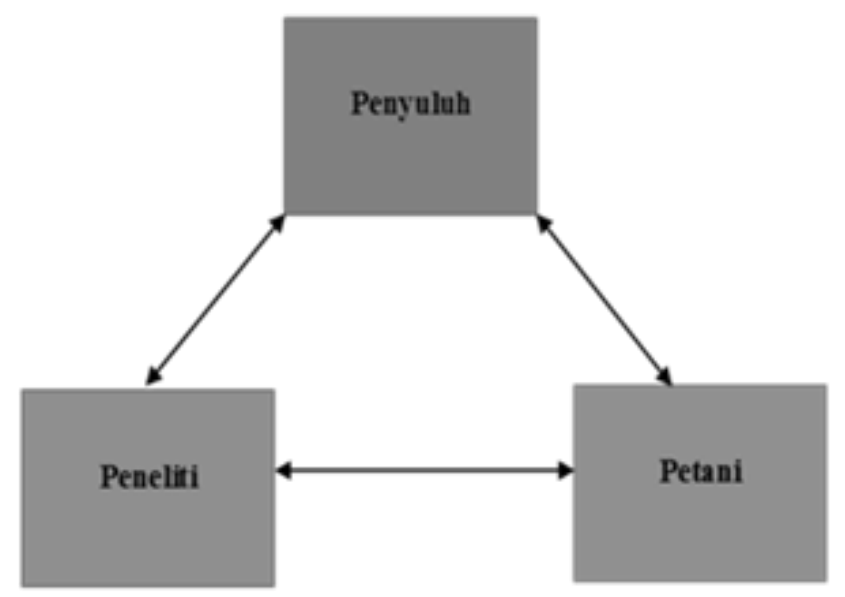

Gambar 3. Model komunikasi jejaring

Penerapan model ini terjadi ketika $\mathrm{P}_{4} \mathrm{~S}$ memberikan wadah kepada para petani untuk tanya jawab mengenai permasalahan yang sedang dan akan di hadapi oleh petani. Dalam melaksanakan hal ini, terjadi dengan dua metode, yang pertama dilakukan pada saat berkumpul di gubuk sawah dan yang kedua dilakukan melalui media sosial yaitu Whatsapp Grup. Melalui proses ini, P4S juga ikut belajar dalam menyelesaikan permasalahan yang sedang dan akan dihadapi oleh petani di Desa Betet.

Dengan adanya Pandemi Virus Corona, membuat penyuluhan yang dilaksanakan dengan tatap muka menjadi berkurang. Penggunaan Whatsapp Grup dioptimalkan untuk membagikan materi penyuluhan mengenai Petani Milenail. $\mathrm{P} 4 \mathrm{~S}$ melalui Whatsapp Grup membagikan artikel dari internet dan juga video dari YouTube. Dalam membagikan materi tersebut, $\mathrm{P}_{4} \mathrm{~S}$ juga menyuarakan pendapatnya, dan pendapat tersebut dapat dikatakan sebagai opinion leader. Dalam hal ini, model komunikasi yang dilakukan adalah model komunikasi media forum. Dapat dikatakan demikian karena $\mathrm{P}_{4} \mathrm{~S}$ dalam memberikan materi melalui Whatsapp Grup. Sumber materi penyuluhan tersebut berasal dari media sosial seperti YouTube dan juga artikelartikel online. Tidak hanya sampai di situ, $\mathrm{P}_{4} \mathrm{~S}$ juga memberikan pendampingan. Dengan kata lain, $\mathrm{P} 4 \mathrm{~S}$ memberikan penjelasan melalui opininya pada saat menyebarkan materi tersebut melalu Whatsapp grup. Pada saat itu juga, terjadi tanya jawab antara penyuluh dan juga petani, sehingga terdapat komunikasi dua arah.

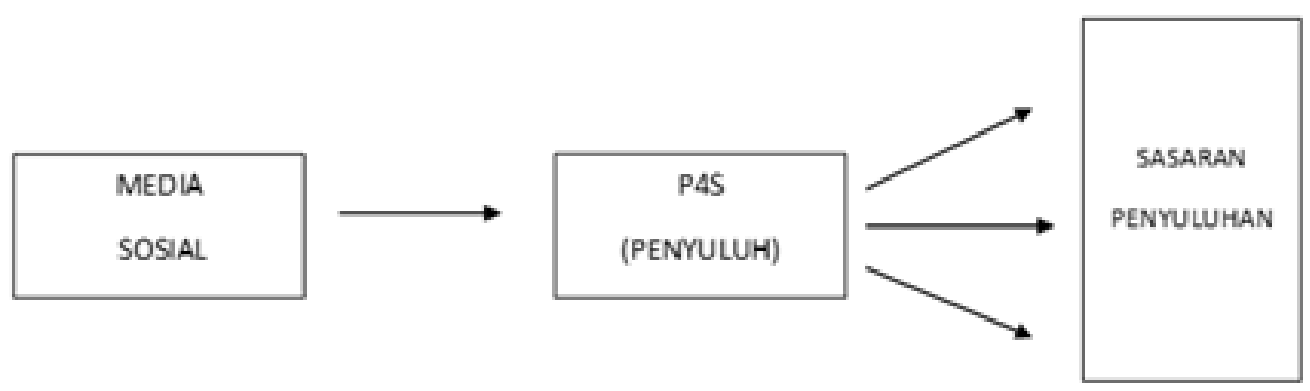

Gambar 3. Model komunikasi media forum 


\section{Keberhasilan penyuluhan Petani Milenial}

Proses pertukaran pesan yang baik akan menimbulkan dampak kepada komunikannya, ada tiga dampak yang ditimbulkan, yaitu kognitif, afektif dan behavioral (Effendy, 2008). Ketika komunikan memiliki presepsi yang sama mengenai pesan yang disampaikan oleh komunikator, maka ini merupakan bentuk dampak kognitif. Pada tahap ini, belum telah mengubah pola pikir komunikan. Hasil temuan di lapangan menunjukkan petani telah memiliki pemahaman yang sama mengenai Petani Milenial yang tertulis pada Peraturan Menteri Pertanian dimana petani milenial merupakan petani yang adaptif dengan teknologi dan inovasi. Petani di Desa Betet telah memahami bagaimana konsep petani yang adaptif dengan teknologi dan inovasi. Namun, pada tahap ini, baru pada tahap kesamaan presepsi. Sebaliknya, keberhasilan sebuah komunikasi haruslah berdampak hingga kepada efek behavioral.

Keberhasilan dalam penyampaian pesan akan terjadi jika terdapat partisipasi dari kedua belah pihak yaitu komunikan dan komunikator (Soekartawi, 1988). Ketika penyampaian pesan pembangunan terutama dalam bidang pertanian harus terdapat aksi dari sasaran pembangunan. Penjelasan ini merujuk pada dampak behavioral, yaitu komikan tergerak untuk melakukan apa yang disampaikan oleh komunikator dengan mempraktikannya.

Selain komunikator yang harus memiliki wawasan luas dan pengalaman dalam dunia pertanian untuk bekal sebagai penyuluh yang memiliki kredibilitas, terdapat peran penting yang perlu dilakukan oleh komunikan ataupun petani yang mendapatkan penyuluhan mengenai pembangunan pertanian. Dari temuan penelitian ini, penyuluh juga memandang demikian. Petani di Desa Betet masih dapat dikatakan tidak banyak yang melakukan partisipasi ataupun aksi dalam mempraktikkan pesan dalam materi Petani Milenial yang disampaikan oleh $\mathrm{P}_{4} \mathrm{~S}$. Alasan mengapa para petani tidak banyak menerapkan pesan yang disampaikan karena ditemui beberapa hambatan yang akan di bahas pada subab kendala dan hambatan.

\section{Kontroling dan evaluasi}

Kontroling merupakan proses ataupun tahapan guna menjamin agar tujuan yang telah ditetapkan berjalan dengan tepat (Handoko, 2016). Pengawan merupakan metode yang digunakan dalam menjalankan sistem agar dapat berjalan pada jalurnya. Fungsi metode ini adalah membuat pelaksanaan program berjalan efektif dan efisien, menumbuhkan motivasi sasaran penyuluhan sehingga materi dapat terserap dengan baik, sebagai standar oprasional untuk menjaga sebuah kualitas dan kuantitas dari keberhasilan program tersebut

Penelitian ini memperlihatkan bahwa pengawasan dilakukan untuk memperkuat pesan program yang telah disampaikan agar para peserta penyuluhan tidak melupakan dan tetap menjalankan program yang telah diberikan. Pemerintah desa sendiri memberikan motivasi kepada petani di Desa Betet agar tetap menjalankan program Petani Milenial yang nantinya memiliki manfaat besar kepada petani itu sendiri. Dari sudut pandang $\mathrm{P} 4 \mathrm{~S}$ selaku penyuluh, dalam tahap pengawasan atau kontrol, materi diberikan kembali kepada Petani Milenial kepada petani-petani di Desa Betet. Selain itu, P4S juga menemukan sebuah ketidakselarasan antara tujuan yang dimiliki oleh pemerintahan Desa Betet 
dengan $\mathrm{P} 4 \mathrm{~S}$ sendiri sehingga dilakukanlan tahapan evaluasi

Evaluasi merupakan tahapan dalam mengkaji dan menilai bagaimana keberhasilan kegiatan komunikasi yang telah dilakukan yang memiliki tujuan untuk memperbaiki serta meningkatkan apa yang telah dicapai (Theresia, 2014). Tujuan evaluasi untuk mengetahui seberapa jauh kegiatan yang telah dilaksanakan. Apakah selaras atau malah menyimpang jauh dari apa yang diharapkan, untuk memperbaiki kembali ketika kegiatan yang dilaksanakan malah melenceng dari apa yang telah ditetapkan?

P4S melihat bahwa tujuan yang dimiliki oleh pemerintah desa hanya sebatas memberikan penyuluhan, dan tidak memberikan tindakan yang lebih untuk merealisasikan program Petani Milenial. Untuk itu, P4S melakukan evaluasi guna memperbaiki hal ini dengan cara melakukan negosiasi dengan Kepala Desa Betet untuk menyelaraskan tujuan yang dimiliki $\mathrm{P}_{4} \mathrm{~S}$ dengan tujuan yang dimiliki oleh pemerintah desa.

\section{Pendukung dan Penghambat Keberhasilan Program Petani Milenial}

Peneliti akan membahas menggunakan analisis SWOT. Analisis ini mencoba untuk melihat bagaimana program Petani Milenial di laksanakan, dan bagaimana kekuatan, kelemahan, peluang serta ancaman yang menjadi penghambat sekaligus pendukung keberhasilan program ini?

Faktor pendukung program Petani Milenial ini dapat ditemukan melalui hasil analisis SWOT pada Strengths dan Opportunities. Pada strengths atau kekuatan, faktor pendukung berasal dari internal. Faktor pendukung internal adalah petani di Desa Betet selalu membudayakan saling berbagi pengetahuan perihal inovasi ataupun program yang berguna untuk memajukan pertanian. Dalam melakukan penyuluhan, penyuluh merupakan pelaku yang telah berhasil dalam melaksanakan program Petani Milenial. Petani telah siap memadukan pertanian dengan menggunakan teknologi. Pada poin peluang, faktor pendukung yang berasal dari luar, yaitu Program Petani Milenial dapat membentuk sistem pertanian yang efektif dan efisien; program yang dimiliki oleh Kementrian Pertanian untuk menuju Indonesia lumbung pangan; adanya peluang untuk para Petani untuk menciptakan sebuah PT (Perseoran Terbukan) dalam satu lingkup kelompok tani, dapat menarik perusahaan untuk melakukan CSR dengan program Petani Milenial di Desa Betet.

Selanjutnya, faktor penghambat. Faktor penghambat berasal dari poin weakness (kelemahan) dan juga threats (ancaman). Pada poin weakness, faktor penghambat yang berasal dari internal, yaitu Minimnya minat dan motivasi petani di Desa Betet terhadap program Petani Milenial; kurangnya modal dan sarana untuk mengembangkan program Petani Milenial; terdapat salah presepsi dalam informasi yang diterima petani; Pemerintah Desa kurang fokus dalam memberikan pelatihan Petani Milenial; perhatian dan dedikasi Pemerintah Desa Betet dapat dikatakan kurang dalam pengembangan Program Petani Milenial.

Faktor penghambat yang berasal dari eksternal terdapat pada threat atau ancaman. Pada faktor ini, petani dihadapkan dengan permainan monopoli pasar dari perusahaan yang terkait dengan pertanian itu sendiri, seperti perusahaan pupuk, perushaan yang mengelola bibit, pestisida dan lain sebagainya. 


\section{KESIMPULAN}

Model komunikasi yang dilakukan $\mathrm{P}_{4} \mathrm{~S}$ dalam menyampaikan program Petani milenial dapat dilihat melalui fase penyuluhan yang telah dilakukan yaitu pada pra penyuluhan sampai dilaksanakannya penyuluhan itu sendiri dan pasca penyuluhan. Melalui dua fase ini, $\mathrm{P} 4 \mathrm{~S}$ menyampaikan program Petani Milenial secara teoritis pada Pra Penyuluhan hingga penyuluhan menggunakan Model Komunikasi SMCR searah dan Model Komunikasi SMCR dua arah. Pada pasca penyuluhan, model komunikasi yang di terapkan adalah Model Komunikasi Jejaring dan Model Komunikasi Media Forum

Hal yang menjadi pendukung dalam pelaksanaan program Petani Milenial ini adalah para petani di Desa Betet gemar dalam berbagi ilmu pertanian. Selain itu, petani di Desa Betet telah siap dengan masuknya teknologi dalam pertanian. Komunikator dalam program Petani Milenial ini merupakan pelaku yang telah berhasil dalam melaksanakan program tersebut, dengan menularkan sistem pertanian yang efektif dan efisien. Pendukung program Petani Milenial ini juga dilihat dengan adanya peluang yang terjadi, yaitu kelompok tani dapat dengan mudah membuat usaha dengan membuka perseroan terbuka pertanian, peluang yang menjadi pendukung dari program ini dapat menarik perusahaan/intansi/lembaga untuk melakukan CSR pada petani, yang terkahir program Petani Milenial sendiri merupakan bentuk upaya dalam mewujudkan Indonesia Lumbung Pangan.

Faktor penghambat dalam program Petani Milenial yang dilaksanakan di Desa Betet adalah minimnya minat dan motivasi petani di Desa Betet. Selain itu, terdapat kurangnya modal dalam melaksanakan program ini dan minimnya saranan untuk melakukan latihan dari materi yang terkait, pemerintah Desa melaksanakan penyuluhan pertanian berbarengan dengan beberapa program yang lainnya sehingga tidak dapat fokus dalam salah satu program. Pemerintah desa dalam memberikan dedikasi dan perhatian dalam program ini juga kurang. Pelaksanaan program Petani Milenial memiliki ancaman dari perusahaan yang terkait dengan bidang pertanian seperti pupuk, bibit, dan segala macam

Penelitian menyarankan kepada Pemerintahan Desa Betet untuk lebih fokus dan memberikan dedikasinya dalam penyuluhan program petani milenial ini, kepada instasi Pemerintah daerah Nganjuk dan Dinas Pertanian Nganjuk disarankan untuk mengambil peran dalam program ini agar dapat menunjang kekurangan fasilitas, sarana, dan prasarana dalam pelaksanaan program Petani milenial. Tak hanya itu, kepada Petani di Desa Betet, diharapkan untuk lebih peka untuk memanfaatkan teknologi sehingga dapat menjadi pelopor petani milenial dan menstimulasi petani di desa lain atau bahkan di daerah lainnya 


\section{DAFTAR PUSTAKA}

Dilla, S. (2007). Komunikasi pembangunan pendekatan terpadu. In Simbiosa Rekatama Media. Simbiosa Rekatama Media.

Effendy, O. U. (2008). Dinamika komunikasi. In Remaja Rosdakarya. Remaja Rosdakarya.

Handoko, T. H. (2016). Manajemen personalia dan sumberdaya manusia. In Badan Penerbit Fakultas Ekonomi. Badan Penerbit Fakultas Ekonomi.

Hariani. (2017). Pola komunikasi Petugas Penyuluh Lapangan (PPL) terhadap petani cengkeh di desa Wa Ode Buri kecamatan Kulisusu Utara kabupaten Buton Utara. Jurnal Ilmu Komunikasi UHO: Jurnal Penelitian Kajian Ilmu Komunikasi \& Informasi, 2(2). https://doi.org/http://dx.doi.org/10. 52423/jikuho.v2i2.2515

Laili, S. F. R. (2014). Pemberdayaan Petani dalam meningkatkan ketahanan pangan (Studi di desa Betet kecamatan Ngronggot kabupaten Nganjuk) [Universitas Brawijaya]. In Universitas Brawijaya. http://repository.ub.ac.id/id/eprint/ 116734

Menteri Pertanian Republik Indonesia. (2019). Peraturan menteri pertanian Republik Indonesia nomor o4 tahun 2019: Pedoman gerakan pembangunan sumberdaya manusia pertanian menuju lumbung pangan dunia (No. 4; Issue 4). https://yuridis.id/peraturanmenteri-pertanian-nomor-4-tahun- 2019-tentang-pedoman-gerakanpembangunan-sumber-dayamanusia-pertanian-menujulumbung-pangan-dunia-2045/

Miles, M. B., \& Huberman, A. M. (1992). Analisis data kualitatif, buku sumber tentang metode-metode baru. In Penerbit Universitas Indonesia (UI Press). Penerbit Universitas Indonesia (UI -Press).

Sadono, D. (2009). Perkembangan pola komunikasi dalam penyuluhan pertanian Indonesia. Jurnal Komunikasi Pembangunan, 7(2), 43-56. https://doi.org/https://doi.org/10.4 6937/720095687

Soekartawi. (1988). Prinsip dasar komunikasi pertanian. In UI Press.

Sugiyono. (2017). Metode penelitian kuantitatif untuk penelitian yang bersifat eksploratif, enterpretif, interaktif dan konstruksi. In Alfabeta. Alfabeta.

Theresia, A. (2014). Pembangunan berbasis masyarakat: Acuan bagi praktisi, akademis, dan pemerhati pengembangan masyarakat. In Alfabeta.

Utami, D. P. (2020). Pengenalan digital marketing dalam pemasaran produk pertanian. Seminar Nasional Karya Pengabdian Fakultas Pertanian Universitas Muhammadiyah Mataram "Peningkatan Daya Saing Hasil Pertanian Menuju Revolusi Industri 4.0," 25-32. 